11. Nastolnaya kniga prepodavatelya inostrannogo yazyka: Spravochnoe posobie (2003).[Foreign Language Teacher Handbook: A Reference Guide]. Minsk, 522 p. [in Belarussian].

12. Sklyarenko, N.K. (1988). Obuchenie rechevoy deyatelnosti na angliyskom yazyke $v$ shkole [Speech activity in English at school]. Kyiv, pp.72-102. [in Russian].

13. Solovova, Ye.N. (2002). Metodika obucheniya inostrannym yazykam: Bazovyy kurs lektsiy: Posobie dlya studentov ped.vuzov $i$ uchiteley [Methods of teaching foreign languages: Basic course of lectures: A manual for students of pedagogical universities and teachers]. Moscov, 239 p. [in Russian].
14. Passov, Ye. I. (1989). Osnovy kommunikativnoy metodiki obucheniya inoyazychnomu obshcheniyu [The basics of communicative teaching methods of foreign language communication]. Moscov, 276 p. [in Russian].

15. Freyre, P. (2003). Pedagogika prignoblenikh [Pedagogy of the Depressed]. 168 p. [in Ukrainian].

16. Chomsky, N. (1986). Knowledge of Language: Its Nature, Origin, and Use. New York.[in English].

17. Available at: http://www.huntesl.com/a-brief-lookat-the-different-esl-teaching-approaches-and-methods/[in English].

18. Available at: http://esl.fis.edu/teachers/support/ method.htm.[in English].

Стаття надійшла до редакції 22.10.2019

УДК 378.011.3-051:373.3

DOI:

Оксана Жигайло, кандидат психологічних наук, доцент кафедри математики, інформатики та методики їх викладання у початковій школі Дрогобицького державного педагогічного університету імені Івана Франка

\title{
ФОРМУВАННЯ ПРОФЕСІЙНОЇ КОМПЕТЕНТНОСТІ МАЙБУТНІХ УЧИТЕЛІВ ПОЧАТКОВОЇ ШКОЛИ ШЛЯХОМ ВИКОРИСТАННЯ ДИДАКТИЧНИХ ТА ДІЛОВИХ ІГОР
}

У статті розглянуто окремі аспекти використання дидактичних та ділових ігор в освітньому прочесі закладів вищої освіти, з метою формування професійної компетентності студентів. Виявлено, щьо гра є найбільш природним і привабливим заняттям не лише для молодших школярів, а й для студентів. Проведено аналіз теоретичних прачь вітчизняних та зарубіжних фахівців, який свідчить, щзо важливим чинником формування у майбутнього педагога важливих особистісних та професійних характеристик є практика впровадження педагогічних інновачій, нестандартних форм, методів організачії навчання студентів.

Ключові слова: дидактична гра; ділова гра; нестандартні методи; інноваційні методики; методика навчання математичної освітньої галузі; студент закладу вищої освіти; початкова школа.

Лim. 13.

Oksana Zhyhaylo, Ph.D.(Psychology), Associate Professor of the Mathematics, Informatics and Methods of Their Teaching at Primary School Department Drohobych Ivan Franko State Pedagogical University

\section{FORMATION OF PROFESSIONAL COMPETENCE OF FUTURE TEACHERS OF PRIMARY SCHOOL BY THE USE OF DIDACTIC AND BUSINESS GAMES}

The article examines some aspects of the use of didactic and business games in the educational process of higher educational establishments, with the purpose of formation of the professional competence of future teachers of primary school. It is showed that the game is the most natural and attractive activity not only for primary schoolchildren, but also for students.

The analysis of theoretical works of native and foreign specialists is carried out. It testifies that the practice of introduction of pedagogical innovations, non-standard forms and methods of the organization of teaching schoolchildren is an important factor of the formation of the future teacher's weighty personal and professional characteristics. The article describes structure, features of the organization and the algorithm of conducting a business game including three stages: preparatory (introductory), basic (conducting a specific type of game) and final (summary of game results, post-game discussion) ones.

It is mentioned that didactic game opens great opportunities for the students' self-realization because the process of game activity forms the motives connected with doing one's duties. The game is a means of communication and self-education, which consists in the acquirement of new knowledge through the dialogue, exchange of thoughts and suggestions.

It is proved that the systematic introduction of such kind of games in the educational process of higher educational establishments makes it possible to intensify he educational activity of students. Such games ensure 


\section{ФОРМУВАННЯ ПРОФЕСІЙНОӤ КОМПЕТЕНТНОСТІМАЙБУТНІХУЧИТЕЛІВ ПОЧАТКОВОЇ ШКОЛИ ШЛЯХОМ ВИКОРИСТАННЯ ДИДАКТИЧНИХ ТА ДІЛОВИХ ІГОР}

formation of stable professional abilities and skills through learning by the use of practical experience in terms of reproduction of reality.

Keywords: didactic game; business game; non-standard methods; innovative techniques; methods of teaching mathematical educational field; a student of higher educational establishment; a primary school.

П остановка проблеми. В умовах впровадження в дію "Нової української школи" та Державного стандарту початкової загальної освіти відбувається реформування загальної середньої освіти. Саме тому, перед закладом вищої освіти, який здійснює професійну підготовку вчителів, одним із вагомих завдань $€$ створення умов для його становлення як педагога-новатора, готового до впровадження інновацій, інформаційних технологій в освітній процес сучасної школи, зацікавленого у навчанні впродовж життя, здатного до професійного розвитку, який володіє навичками критичного мислення, готовий долати перешкоди та осягати цілей, працювати командою, вступати в діалог та дискусію. На цьому наголошуе Педагогічна Конституція Свропи, також Національна доктрина розвитку освіти України, Державний стандарт початкової загальної освіти. На шляху до формування в педагога таких важливих особистісних та професійних характеристик важливим чинником $€$ практика впровадження інноваційних педагогічних технологій, нестандартних форм, методів організації навчання студентів.

На даному етапі реформування освіти в Україні та $з$ урахуванням психологічних основ організації навчально-виховного процесу особливе значення набуває проблема розвитку молодших школярів загалом та в грі зокрема.

Незважаючи на значний потенціал, яким володіє застосування дидактичної гри під час проведення навчальних занять в школі та у вищих навчальних закладах, iї використовують не цілеспрямовано, іноді фрагментами, тому повною мірою не реалізуються усі можливості.

Аналіз останніх досліджень і публікацій. Вітчизняні та зарубіжні педагоги: Н. Анакієва, П.Блонський,А. Макаренко, С.Русова, В.Сухомлинський, К. Ушинський,К. Бюлер, Дж. Дьюї, В. Штейн та ін. наголошували на важливості включення ігрової діяльності в навчальну та обгрунтовували ефективність такого підходу.

Гра $є$ найбільш природним і привабливим заняттям для молодших школярів. К. Ушинський у своїй праці “Педагогические сочинения” писав: “Зробити серйозну роботу для дітей цікавою ось завдання початкової освіти. Кожна здорова дитина потребує активності та серйозної діяльності ... 3 перших уроків навчіть дитину любити свої обов'язки та знаходити задоволення від їх виконання...” [9].

Видатний класик педагогіки А. Макаренко звернув увагу на важливість гри. Вчений наголосив на необхідності врахувати специфіку педагогічного керівництва грою, підкресливши, що вчитель повинен вміти грати як діти $[6,370]$.

Отже, це означає, що вже існувала чітка потреба в науковій підтримці підготовки вчителів з управління іграми, враховуючи специфіку цього виду діяльності.

"Найсерйознішою справа для дитини $є$ гра, сказав В. Сухомлинський, - гра розкриває дітям світ, творчі можливості особистості. Втім, без гри немає і не може бути повноцінного розвитку. Гра - це величезне світле вікно, через яке життєтворчий потік уявлень та уявлень про зовнішній світ перетікає у духовний світ дитини...”. Отже, аналіз педагогічної спадщини педагога-гуманіста показує, що в його очах, гра $\epsilon$ обов'язковою потребою учнів молодшого шкільного віку.

Відомі сучасні педагоги, зокрема Н. Бібік, Я. Коломинський, Ш. Амонашвілі, О. Проскура, О. Савченко вважають, що ігри учнів початкової школи пов'язані із систематичною зміною видів діяльності.

Відомо, що перші дидактичні ігрові системи були розроблені для дошкільної освіти Ф. Фребелем та М. Монтессорі, для початкової освіти О. Декролі. Організаційні особливості дидактичних ігор та їх вплив на розвиток дитини досліджували Е. Тихеєв, Л. Венгер, А. Бондаренко.

Мета статті - проаналізувати та дослідити особливості впровадження дидактичних та ділових ігор в освітній процес з метою формування професійної компетентності майбутнього педагога початкової школи.

Виклад основного матеріалу. Науковці здійснили численні спроби класифікації ігор загалом та дидактичних (навчально-педагогічних) зокрема, проте, з огляду на їх різноманітність, багатофункціональність, варіативність мети, завдань, призначення, єдиної класифікації не існує. Для зручності у користуванні, вважаємо доцільним використовувати узагальнені підходи до розподілу дидактичних ігор, у яких виділені їх суттєві характеристики: характер педагогічного процесу, ігрової методики, ігрове середовище, умови гри, запропоновані С. Куликовським, Н. Седж, В. Аванесовою, Р. Жуковською та класифікації 


\section{ФОРМУВАННЯ ПРОФЕСІЙНОӤ КОМПЕТЕНТНОСТІМАЙБУТНІХ УЧИТЕЛІВ ПОЧАТКОВОӤ ШКОЛИ ШЛЯХОМ ВИКОРИСТАННЯ ДИДАКТИЧНИХ ТАДІЛОВИХІГОР}

дидактичних ігор у закладах вищої освіти, представлені П. Щербанем, М. Фіцулою.

Проаналізувавши численні дослідження особливостей цих видів ігор, ми дійшли висновку, що між ними не існує чіткої різниці, автори часто використовують поняття рольової та ділової гри як синоніми і це виправдано, адже кожну з них можемо визначити як “...засіб моделювання умов професійної діяльності шляхом пошуку способів здійснення цієї діяльності та виокремлення найоптимальнішого з них..." [2]. Схожою $є$ також структура кожної з них, яка передбачає проведення у три етапи: підготовчий, основний та завершальний, наявність ролей, які розігруються в спеціально створених умовах. Проте, вважаємо за необхідне підкреслити суттєву відмінність ділової гри від рольової, яка дозволяє відокремлювати як самостійне кожне з понять, а саме: рольова гра орієнтована на відтворення професійно спрямованих, реально можливих комунікативних ситуацій, в ході яких студенти можуть виконувати ролі педагогів і учнів. Зазвичай такі ігри не передбачають обговорення, а лише програвання. Ділова гра, натомість, обов'язково включає розв'язування проблемних ситуацій, в ході яких студенти зазвичай виконують ролі вчителя, методиста, директора та інших науково-педагогічних працівників, внаслідок чого отримують нове конкретне уявлення про сутність своєї майбутньої діяльності [4].

3 метою підготовки професійної компетентної, соціально активної, творчої особистості педагога, освітній процес у вищому закладі освіти потрібно максимально наблизити до реальної професійної діяльності. Також одним із прогресивних шляхів удосконалення майбутніх учителів є використання інноваційних форм і методів навчання, провідне місце серед яких посідають дидактичні ігри, адже вони створюють умови для залучення студента до безпосередньої участі в освітньому процесі, самостійного пошуку шляхів розв'язання проблем, підвищення рівня пізнавальної активності студентів.

У вищій професійній школі дидактичні ігри з їх багатостороннім аналізом конкретних ситуацій, поєднують одночасно дві сфери людської діяльності - навчання та гру [8]. Це дає змогу використовувати їх як методи активного навчання, встановити нерозривний зв'язок теоретичного матеріалу $з$ практичним досвідом, формувати професійні знання, уміння і навички шляхом залучення студентів до інтенсивної діяльності. Варто зазначити, що на відміну від ігор взагалі, дидактичні характеризуються чітко поставленою навчальною метою з орієнтацією на відповідний педагогічний результат.
Одним із прогресивних методів організації навчання студентів є ігрова форма (О. Бреус, I. Куліш, Г. Романовський, Ю. Панфілов). Згідно 3 проведеним дослідженням, міра засвоєння слухачами матеріалу в ігрових формах навчання становить 90\%, на відміну від інших (на лекції$20 \%$, на лекції з використанням наочних посібників - 30\%, з використанням аудіовізуальних засобів - 50\%, при проведенні дискусій на семінарах $70 \%)$.

“Використання дидактичних ігор, за Н. Мачинською, сприяє перетворенню студента 3 об'єкта навчання на предмет професійно спрямованої праці, яка обумовлює його цілеспрямовану активність та творчу участь у самостійному формуванні професійної компетентності” [7, 20]. Подібну думку висловлює американський вчений П. Пурмена стверджуючи, що “продуктивне навчання не має місця, коли студенти постають як пасивні спостерігачі освітнього процесу" [13].

Використання методу ігрового навчання сприяє розвитку творчих можливостей студентів в процесі активної пізнавальної діяльності, під час якої у студентів проявляється ініціатива, самостійність, самодіяльність, виробляється активна позиція, створюється емоційна й інтелектуальна атмосфера, психологічний комфорт, сприятливі умови для розвитку умінь займати активну позицію; навичок самоуправління (самоорганізації, самореалізації, самоконтролю) особистою діяльністю [1, 24]. Застосування ігрових технологій сприяє також формуванню готовності вчителів до інноваційної педагогічної діяльності, яка є необхідною умовою ефективної діяльності педагога, максимальної реалізації учительських можливостей та творчого потенціалу.

Значною перевагою участі в ігровій діяльності $\epsilon$ сприяння прояву емпатійного ставлення та розуміння інших. Емпатія, на думку Г. Нейнера це "здатність поставити себе на місце іншої людини, зрозуміти її думки, відчуття, чекання і вчинки...” [12]. До найбільш ефективних прийомів формування емпатії можна віднести "втілення" учасників навчального процесу в ролі інших людей, адже під час цього процесу учасники переживають ситуацію емоційно, намагаються відчути, що саме хтось переживає. Крім цього, емпатія, як здатність відчути настрій, стан, почуття іншої людини, зрозуміти їі потреби та очікування, відіграє важливу роль у запобіганні конфліктним ситуаціям та виробленні способів їх конструктивного вирішення [3].

Дидактична гра відкриває перед студентам 
великі можливість самореалізації, позаяк в процесі ігрової діяльності формуються мотиви, пов'язані з виконанням своїх зобов'язань. Студент вчиться розраховувати на свої можливості, їх оцінювати, емоційно збагачується. Таким чином, гра - це засіб спілкування та самовиховання, що полягає у отриманні нових знань, отримувати їх завдяки діалогу, обміну думок та пропозицій, обговоренню і дискутуванню.

Незважаючи на деякі труднощі у використанні дидактичних ігор, серед яких найчастіше було згадано трудомісткість та значні затрати часу на їх підготовку, переваги їх залучення в процес професійної підготовки студентів переважають. Значна частина науково-педагогічних працівників відносять до них такі: забезпечення умов для виявлення індивідуальних особливостей студентів, розвитку їх творчих здібностей, критичного мислення, створення позитивного мікроклімату в групі, сприяння інтерактивній міжособистісній та груповій взаємодії [11].

Проведений аналіз дає змогу зробити висновок про те, що дидактичні ігри є одним з важливих шляхів підвищення професійної компетентності вчителів початкових класів, тому необхідно забезпечити систематичне їх використання на практичних заняттях у вищих навчальних закладах. Проаналізувавши результати анкетування викладачів, а також відповідні літературні джерела, ми побачили потребу серед розмаїття дидактичних ігор звернути особливу увагу на ті їх види, які спрямовані на здобуття знань, умінь та навичок тої чи іншої професії, поведінковими моделями та соціально-психологічних відносин, орієнтують на творчий пошук систематичного вирішення проблем в конкретних ситуаціях, а саме: навчально-педагогічні рольові та ділові ігри. Їх використання практичній демонстрації професійної реальності у студентській аудиторію, тобто абстрактне вивчення теорії навчальної дисципліни переноситься на закріплення знань через практику у вигляді моделі професійної діяльності. Відтак доречно вести мову не про засвоєння, а саме про поглянання знань, умінь та навичок, глибокого їх усвідомлення.

Для забезпечення ефективності ділової гри необхідно враховувати методику ії підготовки та проведення. В ході ділової (рольової) гри студенти беруть на себе певні ролі, або виступають як активні глядачі, які аналізують та оцінюють дії учасників гри. Згідно з дослідженнями авторів, в структурі ділової (рольової) гри виділяємо три етапи:

1. Підготовчий (ввідний);

2. Основний (проведення конкретно вказаного виду гри);
3. Завершальний (підсумок результатів гри, післяігрова дискусія).

На підготовчому етапі потрібно:

- визначити тему гри і змоделювати проблемну ситуацію;

- сформулювати мету гри, встановити правил;

- опрацювати чітко завдання;

- затвердити організацію гри, форму проведення;

- розприділити посадові ролі;

- змоделювати навчальну ситуацію на основі оброблених матеріалів;

- видати експертам та іншим учасникам пакет документів, що допомагають розв'язати дидактичну задачу;

- вивчення настановчих матеріалів;

- збір та організація додаткової інформації;

- отримання від вчителя, експертів інформації;

- встановлення контактів між учасниками ігор, якщо це необхідно;

- обробити документи, підготувати навчальнометодичну базу.

В процесі другого етапу, що фактично $є$ діловою грою, учасники виконують мовленнєві дії відповідно до проблемної ситуації та ролей. Моделювання у грі реальної ситуації професійної діяльності повинно відбуватися 3 дотриманням усіх дій.

Необхідно підкреслити, що роль викладача у процесі гри буває різною і залежить від рівня комунікативної підготовки учасників спілкування. Якщо цей рівень високий, викладач мінімально вмішується в перебіг гри, а є лише спостерігачем, що повинен фіксувати помилки студентів, слідкувати за спілкуванням учасників. Якщо рівень комунікативної підготовки студентів недостатній для самостійного ведення гри, викладач стає повноправним учасником спілкування, програючи, наприклад, одну 3 головних ролей.

Особливу увагу слід приділити завершальному етапу у формі дискусії, який полягає у:

- виявленні проблемних моментів, явища, що відбулися в грі;

- демонстрації перенесення гри у реальне життя;

- оцінені рішень, їх доцільності, виявленні причин різнопланової поведінки учасників;

- визначенні доцільності даної поведінки у реальному житті, з метою досягнення кращого результату запропонувати зміни;

- аналізі змін у поведінці, стилі і чи можна використати дану модельовану ситуацію у майбутній професійній діяльності $[1,29]$.

Позаяк, спонтанні ділові (рольові) ігри 


\section{ФОРМУВАННЯ ПРОФЕСІЙНОӤ КОМПЕТЕНТНОСТІ МАЙБУТНІХУЧИТЕЛІВ ПОЧАТКОВОӤ ШКОЛИ ШЛЯХОМ ВИКОРИСТАННЯ ДИДАКТИЧНИХ ТАДІЛОВИХІГОР}

виділяють в окрему групу, то варто звернути увагу на етапи ії проведення безпосередньо на занятті (за Т. Хлєбніковою): “...оголошення мети й завдання на початку заняття; організаційний момент: розподілення на групи, розподілення ролей і пояснення завдання кожної ролі; підготовка студентів до програвання ситуації у створених групах; презентація групами ділової гри; підведення підсумків гри; оцінювання студентів" $[10,54]$.

Поділяємо погляд О. Кочерги “...виконання ролі вчителя, 3 огляду на професійну зорієнтованість, є найбільш результативною, тому організовуючи ділову гру, доцільним вважаємо кілька разів програвати ту саму ситуацію 3 різними учасниками, після чого, у процесі дискусії, порівняти й оцінити дії кожного з них...” $[5,369]$. Це забезпечить учасникам можливість продемонструвати і побачити індивідуальні особливості виконання однієї й тієї ж соціальної ролі і сприятиме виробленню в учасників гри навичок адекватного аналізу своєї та чужої поведінки, ії коригування. Отже, проведений аналіз наукової та методичної літератури дає підстави стверджувати: освітній процес підготовки вчителя початкової школи потребує якісного вдосконалення шляхом впровадження інноваційних методів навчання, зокрема дидактичних та ділових ігор, в системі яких особливим потенціалом володіють ділові ігри.

Висновки. Систематичне впровадження ігор даного виду у освітній процес закладу вищої освіти дає змогу активізувати та інтенсифікувати навчальну діяльність студентів, забезпечує формування стійких професійних вмінь і навичок шляхом здійснення навчання через практичний досвід в умовах відтворення реальної дійсності, сприяє підвищенню навчальної мотивації студентів, готовності до здійснення інноваційної діяльності, розвитку творчих здібностей, вдосконаленню вмінь та навичок соціальної взаємодії, професійного спілкування та колективного прийняття рішень, вдосконалюють здатність майбутніх фахівців до самоаналізу й узагальнення. Завдяки активній позиції особистості у діловій грі відбувається зростання iii самосвідомості, задовольняється іiї прагнення до самоствердження, потреба в самооцінці через взаємодію 3 іншими, збагачується ㄲï комунікативний та професійний досвід.

\section{ЛІТЕРАТУРА}

1. Бреус О. В. Навчально-ігрові технології як засіб формування інноваційного потенціалу майбутнього вчителя початкових класів в освітньому процесі ВНЗ. Гуманітарний вісник ДВНЗ “Переяслав-Хмельницький державний педагогічний університет імені Григорія Сковороди": зб. наук. праць. ПереяславХмельницький, 2012. Вип. 24. С. 28-32.

2. Голозубова О.В.Ефективність використання дидактичних ігор у процесі вивчення економічних дисциплін. Наукові записки кафедри педагогіки. 2014. Вип. 34. С. 51-57.

3. Елькін О. Українська правда. Педагоги надто важливі. Що новий закон про освіту дасть вчительству. URL: https://life.pravda.com.ua/ columns $/ 2017 / 06 / 30 / 225026 /$

4. Кожушко С. П. Дидактичні ігри як засіб підготовки майбутніх фахівців комерційної діяльності до професійної взаємодії/ Педагогіка формування творчої особистості у вищій і загальноосвітній школах, 2013. Вип. 28. С. 184 191.

5. Кочерга О. Використання ділової гри у процесі формування соціальної відповідальності майбутніх учителів початкових класів. Проблеми підготовки сучасного вчителя. 2012. № 6(3). C. $49-56$.

6. Макаренко А. С. Гра. Твори : В 7 т. Київ, 1954. T. 4. C. $367-368$.

7. Мачинська Н. І. Впровадження ігрових технологій навчання у практику підготовки майбутніх магістрів. Наукові праці Чорноморського державного університету імені Петра Могили комплексу “Києво-Могилянська академія”. Сер.: Педагогіка. 2011. Т. 158, Вип. 146. C. $18-22$.

8. Очеретна Н. Д. Особливості застосування ділових ігор у процесі вивчення іноземної мови у вищих навчальних закладах. Педагогічна освіта: теорія і практика. 2013. Вип. 14. С. 206-210.

9. Ушинский К.Д. Педагогические сочинения: в 6-ти т. / сост. С.Ф. Егоров. Москва, 1990. Т. 5. $528 \mathrm{c}$.

10. Хлебнікова Т. М. Ділова гра як метод активного навчання педагога. Харків, 2003. 80 с.

11. Щербань П. М. Навчально-педагогічні ігри у вищих навчальних закладах: навч. посіб. Київ, 2004. C. 24-41.

12. Neuner G., Vermittlungskonzepte: Historischer Uberblick. In: Bausch, Karl-Richard (Hrsg.): Handbuch Fremdsprachenunterricht. 4. Auflage. Tubingen. Basel, 2003. 184 p.

13. Poorman P. B. Biography and role-playing: fostering empathy in abnormal psychology. Teaching of Psychology. 2002. Vol. 29(1). P. 32-36.

\section{REFERENCES}

1. Breus, O. (2012). Navchalno-ihrovi tekhnolohii 
yak zasib formuvannia innovatsiinoho potentsialu maibutnoho vchyteliapochatkovykh klasiv v osvitnomu protsesi VNZ [Educational-game technologies as a means of formation of innovative potential of the future teacher of elementary classes in educational process of high school]. Humanitarian Bulletin of the Pereyaslav-Khmelnitsky State Pedagogical University named after Grigory Skovoroda: Coll. Sciences. wash, Vol. 24, pp. 2832. [in Ukrainian].

2. Holozubova, O. (2014). Efektyvnist vykorystannia dydaktychnykh ihor u protsesi vyvchennia ekonomichnykh dystsyplin [The effectiveness of the use of didactic games in the study of economic disciplines]. Scientific notes of the Department of Pedagogy. Vol. 34, pp.51-57. [in Ukrainian].

3. Elkin, O. Ukrainska pravda. Pedahohy nadto vazhlyvi. Shcho novyi zakon pro osvitu dast vchytelstvu [Ukrainian Pravda. Teachers are too important. What a new law on education will give teachers]. Available at: https://life.pravda.com.ua/ columns/2017/06/30/225026/ [in Ukrainian].

4. Kozhushko, S. (2013). Dydaktychni ihry yak zasib pidhotovky maibutnikh fakhivtsiv komertsiinoi diialnosti do profesiinoi vzaiemodii [Didactic games as a means of preparing future professionals of commercial activity for professional interaction]. Pedagogy of creative personality formation in higher and secondary schools, Vol. 28., pp. 184191. [in Ukrainian].

5. Kocherha, O. (2012). Vykorystannia dilovoi hry $\mathrm{u}$ protsesi formuvannia sotsialnoi vidpovidalnosti maibutnikh uchyteliv pochatkovykh klasiv [Use of the business game in the process of forming the social responsibility of future primary school teachers]. Problems of preparation of the modern teacher. No. 6(3), pp. 49-56. [in Ukrainian].
6. Makarenko, A. (1954). Hra [Game]. Kyiv, Vol. 4, pp. 367-368. [in Ukrainian].

7. Machynska, N. (2011). Vprovadzhennia ihrovykh tekhnolohii navchannia u praktyku pidhotovky maibutnikh mahistriv [Introduction of game training technologies into the practice of preparing future masters]. Scientific works of the Black Sea State University named after Peter Mohyla Complex “Kyiv Mohyla Academy”. Ser .: Pedagogy, Vol. 158, Vol. 146, pp. 18-22. [in Ukrainian].

8. Ocheretna, N. (2013). Osoblyvosti zastosuvannia dilovykh ihor u protsesi vyvchennia inozemnoi movy u vyshchykh navchalnykh zakladakh [Features of the use of business games in the process of learning a foreign language in higher education]. Teacher education: theory and practice, Vol. 14, pp. 206-210. [in Ukrainian].

9. Ushynskyi, K. (1990). Pedahohycheskye sochynenyia: v 6-ty $t$. [Pedagogical works: in 6 volumes].(Ed.).S.F. Ehorov. Moscov, Vol. 5, 528 p. [in Ukrainian].

10. Khlebnikova, T. (2003). Dilova hra yak metod aktyvnoho navchannia pedahoha [Business play as a method of active teacher training]. Kharkiv, 80 p. [in Ukrainian].

11. Shcherban, P. (2004). Navchalno-pedahohichni ihry $u$ vyshchykh navchalnykh zakladakh: navch. posib. [Educational and educational games in higher educational establishments]. Kyiv, pp. 24-41. [in Ukrainian].

12. Neuner, G. (2003). Vermittlungskonzepte: Historischer Uberblick. In: Bausch, Karl-Richard (Hrsg.): Handbuch Fremdsprachenunterricht. 4. Auflage,Tubingen. Basel, 184 p.[in German].

13. Poorman, P. (2002). Biography and roleplaying: fostering empathy in abnormal psychology. Teaching of Psychology. Vol. 29(1). P. 32-36. [in English].

Стаття надійшла до редакції 26.09.2019

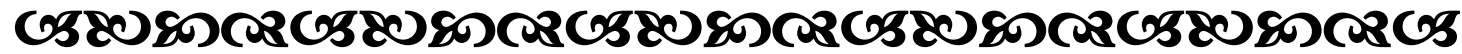

"Тра - вид діяльності дітей, що полягає у відтворенні дій дорослих і відносин між. ними, спрямований на орієнтування й пізнання предметної та соиіальної дійсності”.

Тедагогічна енииклопедія

“Не роби ніколи того, чого не знаєш. Але навчися всього, що слід знати".

Tіфбагор Самоський давньогреиький ббілособ

“Несқінченне прагнення бути қращим є обов'язқом людини. Iू вже саме по собі $є$ винагородою. Все інше в рукахБожих".

Махатма Тандi

індійсъқий державний і політичний діяч

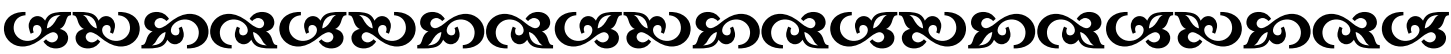

Молодь і ринок №11 (178), 2019 